\title{
Service Learning as Justice Advocacy: Can Political Scientists Do Politics?
}

\author{
Tony Robinson, University of Colorado, Denver
}

$I_{\mathrm{r}}$ n a 1997 APSA plenary address, Ralph Nader questioned the value of political science. "You all study power," he noted. "And yet, how strange it is that I don't know anyone in power who is the least bit afraid of a political scientist! With the way you conduct your research, the material that is published, and the way you teach, you political scientists have managed to make yourselves irrelevant to the world of power and politics!" In short, Nader charged everyone in the audience with incompetence, irresponsibility, or indifference. He must have struck a chord, because the audience erupted into applause.

\section{The Divided Life of Political Scientists}

Palmer (1996) has argued that many political scientists live "divided lives." They believe in "the common good," in civic engagement, and in action for change, but they teach in accordance with the "ivory tower" model, stressing facts and research methods divorced from the practical application of ideals of political change. Many instructors teach about social problems, and hope students will engage such problems, but their classes are rarely oriented in any practical way toward creating informed, collective action by students. Adding to the irony, as Ralph Nader and Philip Nyden et. al. (1997) correctly observed, is that too much academic research is focused on advancing knowledge within the

Tony Robinson is an assistant professor at CU-Denver. He coordinates his department's service learning requirement and internship programs, and also directs the Westside Outreach Center-a HUD funded community organizing and re search center. He has been involved in service learning and justice advocacy for 10 years and has done research on grassroots organizing, urban political economy, and the politics of housing development. discipline itself, and too little is focused on advancing "social knowledge," or on how to find practical solutions to social problems. Political scientists devote themselves to understanding and advancing "freedom" and "justice," yet a vast amount of their research can barely be understood or applied by those in power or by activists working at the ground level. Scholars truly dedicated to community service and to helping students become effective actors in promoting a more just society are generally passed over for tenure in favor of "professors [who] maintain their elite positions through conspiring with a research and publication reward system that produces countless articles and books of self-serving theory of limited use that often is only intelligible to scholars within one's own circle" (Lisman 1997, 84). Accommodating to this system, dominated by the methodologies of scientism, encourages the use of exclusionary jargon and esoteric algebraic and logical reasoning processes that can isolate the political science community from even the most informed of the broader political community. Alan Ehrenhalt (1988), a past editor of Congressional Quarterly, once remarked that he "didn't know a single office-holder who would choose to read the APSR, or who would recognize themselves or their peers in the articles about congressional behavior that appeared therein."

It does not have to be this way. There are many scholars and even organized sections of the APSA (e.g., race and ethnicity, ecological and transformational politics, new political science) that work to build a more socially engaged scholarship. Members of the undergraduate education section, for example, have begun advocating adding "service learning" courses to political science curricula. A key goal of service learning advocates is to reduce the isolation of scholars from their surrounding communities while also addressing the pedagogical needs of students to act on their knowledge, to test ideas against reality, and to study politics with a purpose. Some universities, like Portland State, and some departments like CU-Denver's political science department, now require service learning (field experience in a community agency, local government, or other applied venue) in order to graduate.

Marking the growing consensus for the need to foster civic engagement through service learning and a related scholarship of action, APSA formed the Task Force on Civic Education 1996. The Task Force issued a statement in 1988 setting forth its objective that instruction in political science should "teach the motivation and competence to engage actively in public problem solving" (1998, 636). Despite such developments, the pages of the APSR and many other prestigious academic journals reveal the continued dominance of narrow tools of instrumental scientism, the continued commitment to dispassionate academic neutrality, and the absence of the kind of engaged scholarship that might, in fact, teach and motivate active problem solving by the disengaged populace. Though action research and service learning are growing in acceptance, the related movements have yet to reach their potential, and modern advocates have yet to gain the influence enjoyed by service learning trailblazers.

\section{Infellectual Roots: The Settlement House and SDS}

The roots of recent service learning developments are to be found in the turn-of-the-century Settlement House model and in the "action university" model proposed by the Students for a Democratic Society (SDS) in the early 1960s. In the 
midst of Chicago's slums of the late 1800s, Jane Addams opened Hull House: "a clearinghouse for every kind of social service, an experimental laboratory in social reform, in art and music and drama and education as well; she made it a school of citizenship and a university of social service" (Commager 1960, xii). Addams welcomed Chicago's poor, together with university faculty and students, to her Settlement House to participate in food giveaways, English instruction, medical care, schooling, arts and culture celebrations, and alcohol and mental counseling. Hull House also became a center of political agitation.

Addams and her colleagues pushed for new labor laws, establishing juvenile courts, paving neighborhood roads, enforcing housing and sanitation laws, granting women's suffrage, and politicizing immigrants.

Hull House brought the educated and the affluent into active partnerships with the uneducated and impoverished residents of Chicago's slums. Addams believed this process was necessary to ameliorate the listless ennui she detected among her mostly female, college-educated peers who felt a deep need to work for social progress but found few avenues to do so. Deploying university resources for social purposes proved extraordinarily fruitful. "It was no accident," Commager argued, "that the new University of Chicago, which was founded just a few years after Hull House, came to be the center of sociological study in America, and that so many of its professors were intimately associated with Hull House" (ix). Though Hull House-influenced sociology soon developed into a dispassionate social science, dominated by the scholar- ship of academic distance and scientific objectivity, many early academicians associated with Hull House were committed to a scholarship of action and reform.

During the 1960s, as best captured in the 1962 Port Huron Statement, calls for making university learning more relevant by preparing individuals to address problems such as poverty, racial inequality, and militarism reemerged. The authors of the Port Huron Statement detected the same ennui that Addams had found among the educated youth of her era. Almost 40 years before Putnam, the Port Huron authors bemoaned the disappearance of what we now call "social capital," as indicated by "loneliness, estrangement, isolation," "the rise of a democracy without publics," "emptiness of life," and the "withdrawal from public life" (Miller 1987, 332-35). The students did not accept this state of affairs. Tom Hayden, the statement's principal author, argued that "the victims of social injustice" demanded reform, and "I don't think there's anything more satisfying politically than to be young in spirit, and to believe the world is yours to change" (325). Just as Addams had, the authors of the Port Huron Statement looked to educated youth as a source of change: "From where else can power and vision be summoned?" they asked rhetorically. "We believe that the universities are an overlooked seat of influence" (373). It is from the universities that students hoped to "build a base for their assault upon the loci of power" (374).

Although SDS activists recognized the potential of the university to function as an agent of social transformation, they also recognized the profound failure of the university to live up to its promise.
The university "prepares" the student for "citizenship"... through emasculation of what cre- ative spirit there is in the individ- ual. .. . Further, academia in- cludes a radical separation of the student from the material of study. That which is studied, the social reality, is "objectified" to sterility, dividing the student from life. ... The specialization of function and knowledge . . . has produced an exaggerated compartmentalization of study and understanding. This has contributed to an overly paro- chial view, by faculty, of the role of research and scholarship; to a discontinuous and truncated un- derstanding, by students, of the surrounding social order; and to a loss of personal attachment, by nearly all, to the world of study as a humanistic enterprise. . . (334-35)

\section{A Modern Variant on the Theme: Service Learning and Action Research}

Across academia, a service learning/action research movement is growing among instructors who believe such critiques of university irrelevance remain timely. These instructors hold that service learning should be a key component of higher education, especially an advanced political education. Proponents argue that linking students and faculty to community-based organizations and performing community service projects addresses social needs by bringing university resources into distressed communities, meets the moral need of youth to find ways to serve their community, and develops strong citizenship skills among alienated youth (Barber 1999; Carr 1999; Gorham 1992; Nyden et al. 1997; Rhoades 1998; Stringer et al 1997). For example, Rimmerman (1997) has argued that students often seek forms of civic engagement as a way to overcome their brooding sense of helplessness and cynicism, but they often cannot find them within the traditional academy. When they do find such opportunities, often through service learning, students begin to rise out of apathy and alienation and to de- 
velop a critical social conscience and engaged patterns of citizenship.

One means to familiarize students with the tools of civic engagement is participatory action research, whereby research methods courses are designed to help students complete applied research in cooperation with community organizations. Training students how to collaborate with community agencies, how to design research projects that yield practical results of real use to people, and how to communicate research findings so they have maximum social effect, prepares them to reach beyond the university and respond to societal needs. Incorporating action research into curricula requires professors to resist the claim that "the production of social science represents value-free, politically neutral activities." Acceptance of this claim has too often led researchers "to be agnostic about either who uses or needs their work or even what it is about. As a result, much social science research is either of limited utility (because of its irrelevance to real-world problems) or inaccessible (because of the method of presentation or form of publication-for example, in obscure academic journals)" (Ferman and Shay 1997, 129). Alternatively, community-based research results in the production of socially responsive knowledge, so that "faculty begin to see that they have a moral and social responsibility to use their 'intellectual capital' in the service of the community rather than in the service of professional mobility" (Lisman 1997, 86).

\section{Service Learning as Charity; Service Learning as Justice}

There is a division of thought in this emerging celebration of service learning. The division emerges between that kind of service learning that provides direct, charitable services to needy communities (e.g., conducting food drives, painting houses, cleaning up streets, counseling), and that kind of service learning that engages students in political organizing and social advocacy. Most service learning activities na-

tionwide are of the former sort. In

fact, "justice advo-

cacy" service learn-

ing has been widely

discredited across

the academy, due to

its potential to "po-

liticize" education

(see Lisman 1998).

Discrediting justice

advocacy service

learning seems

strange, however,

when one considers

the claims service

learning proponents

often make regard-

ing the socially bene-

ficial results of par-

ticipating in service

learning. According

to its advocates, ser-

vice learning can

"heal a divided society" (Barber 1999),

"cure the patholo-

Service learning

programs that

merely feed stu-

dents into short-

term, or even one-

time, volunteer or

low-paying activities

that deal with the

fallout of the sys-

tem, provide poor

training for critical

citizenship, political

reasoning, or social

transformation. gies of society" (Gorham 1992, 8),

equalize life opportunities across

classes (U.S. Department of Housing and Urban Development 1999), and restore in participants a sense a civic connection and responsibility (Barber 1998). One scholar has even gone so far as to conclude that service learning is "crucial to the survival of American society" (Kraft 1999, 8).

It should be clear that achieving such grand results will take the mobilization of a tremendous movement for change, and that sparking such a movement will entail political advocacy and conflict. Most practitioners of service learning, however, do not admit this. As a whole, service learning advocates are decidedly apolitical, profoundly leery of any association with "justice advocacy," and all too willing to channel students into narrowly defined, directservice, therapeutic activities with professional organizations and to caution students against involving themselves in conflict-ridden movements that carry the possibility of social transformation. Though tremendous good work is being done in the name of service learning, the depoliticized rendering of direct services to needy populations makes service learning a glorified welfare staging painta-thons, tutoring, reading for the blind, and planting trees (quoted in Kraft 1999, 12). Clearly, these kinds of activities benefit millions of individuals. Yet, where on this list are activities that address the structural roots of problems, that aim at uniting citizens in action for change? Where is tenant organizing? Union organizing? Advocacy for the homeless? Welfare rights organizing? Such explicitly political organizing, entailing an action-oriented critique of society, is anathema to today's service learning proponents. Painting the decaying homes of low-income renters with student labor brings celebration from institutional powers, but the merest hint of actually working with renters to build a tenants' union to address systematic exploitation by slumlords is forbidden out of hand.

As Gorham (1992) has noted, service learning programs that merely feed students into short-term, or even one-time, volunteer or lowpaying activities that deal with the fallout of the system, provide poor training for critical citizenship, political reasoning, or social transformation. A service learning language of individualistic therapy and "helping," rather than a language of political resistance, conflict, and social 
transformation, silences the citizens as they are plugged into apolitical "bricks and mortar" projects that cannot foster the development of what Rimmerman calls "a culture of civic engagement, one where [students] are central participants in promoting political and social change" $(1997,28)$.

Their willingness to defend directservice service learning projects, and their equal readiness to argue against politicized "action reseach" agendas, gives strong evidence of many service learning proponents' unwillingness to acknowledge that their goals of "improving society" and "curing social pathologies" will require political action and bring them and their students into conflict with the current holders of privilege. If instructors do not advance such political agendas explicitly, they are relegating students in service learn- ing programs to acting as a glorified providers of social welfare services and ensuring that their oft-articulated promise to cure social pathologies will be little more than a platitude.

\section{CU-Denver's Westside Outreach Center and Urban Citizen Project}

Today, a service learning program at the University of Colorado, Denver (the Westside Outreach Center and its associated Urban Citizen course) attempts to replicate the justice advocacy values advanced in the Settlement House and SDS models. The Urban Citizen course is facilitated by two faculty members (myself and Professor Jerry Jacks), and is one of several options for fulfilling CU-Denver's service learning

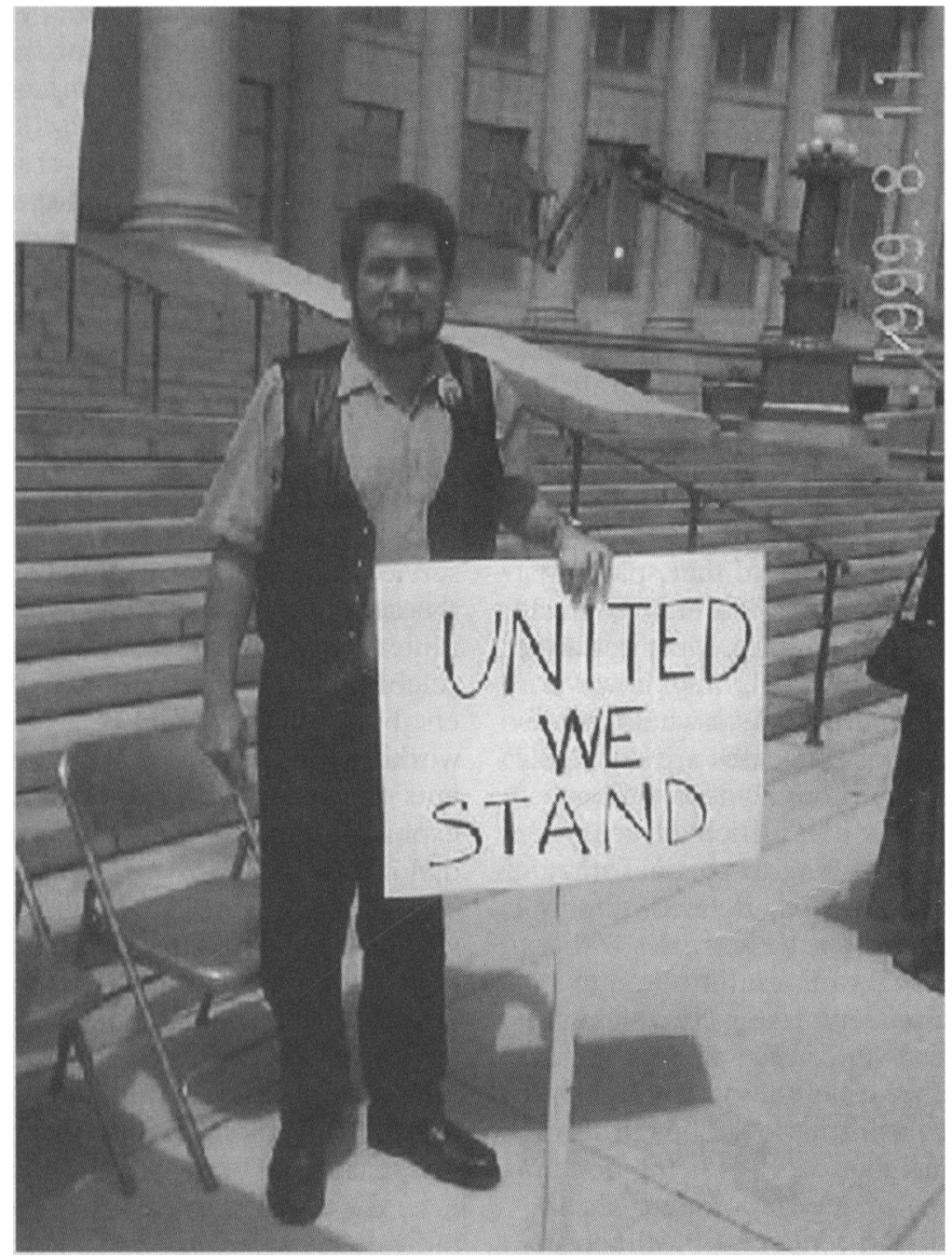

A neighborhood resident stands up for affordable housing.

Photo courtesy of Tony Robinson. requirement in political science. The heart of the class involves a group project that requires students to meet off-campus at the office of a nonprofit organization located in a low-income neighborhood, to engage in discussion seminars with representatives of community groups, and to design projects of interest to those groups. Although class projects include bricks and mortar service activities (e.g., rehabilitating a transitional living center for Native Americans), they also include community organizing and political agitation (e.g., organizing a tenants' union).

Meeting in the heart of a lowincome neighborhood requires students to leave the campus and walk through the streets of a Latino barrio before they reach the class site, to directly view and experience the neighborhood issues they will discuss in meetings with community representatives and residents. The academic work of the class involves seminars to discuss community development, urban poverty, and service learning pedagogy. The power of the discussions that emerge while students are immersed in a "realworld" setting is far beyond the power of any campus-based discussions of urban poverty and community development I have observed. Students also attend weekly action meetings on various community service and research projects of the class, and we encourage them to simply "hang about" in the community, to attend community events and meetings, to patronize local businesses, to walk the streets, and to volunteer for community activities.

The Urban Citizen course laid the foundation for CU-Denver's successful 1998 proposal to the U.S. Department of Housing and Urban Development (HUD) to expand the course into a community organizing and research center. Funded through HUD's Community Outreach Partnership Program, the Westside Outreach Center (WOC) (http://westside.cudenver.edu) has over a million dollars to spend to bring students and faculty into action-engagement with low-income neighborhoods bordering the cam- 
pus of CU-Denver. Neighborhood residents are brought into WOC's programs through tuition grants and are provided leadership opportunities, most notably as WOC employees and interns. The center also turns over $\$ 25,000$ a year in university funds to a resident-driven advisory board to spend on neighborhood organizing efforts and efforts to build partnerships with the university.

WOC advances the community organizing and political agitation philosophies of the Settlement House and SDS models and supports transformative political activity to leverage neighborhood uplift. The students brought into the neighborhood through WOC are not steered clear of politics. Indeed, with WOC being funded to do community organizing, tenant organizing and neighborhood mobilization, it is hard to see how the students it sponsors could be steered clear of politics. When political scientists talk of realistic revitalization and transformation of inner-city slums, they must also realize that political and economic transformation must occur in the broader community.

The explicitly political activities of WOC employees, interns, and neighborhood partners have been numerous over the last few years. People affiliated with the center have initiated progressive neighborhood planning campaigns, a "radical walking tour" project, a welfare rights organizing campaign, investigation into violations of fair housing laws (followed by protests and lawsuits), efforts to build tenants' associations against the will of their landlords, union organizing campaigns, a neighborhood downzoning campaign, vigorous efforts to modify harsh policing tactics in the community, and a movement to stop the expansion of university housing into the community. In the following paragraphs I will detail only one of these campaigns: The Save Our Section 8 Housing campaign (http:// westside.cudenver.edu/sos8).

The Save Our Section 8 (SOS8) campaign emerged from a lengthy outreach process. During the fall of
1997, Urban Citizen students completed a door-to-door canvassing project, speaking with residents about their concerns. The intent was to discover the common issues faced by residents and to build residents' interest in organizing to ensure those issues were properly addressed. The most common problem faced by the low-income residents were rising rents, inadequate living conditions, and landlord neglect or abuse. Over the course of the semester, the Urban Citizen students built the knowledge and set of neighborhood contacts needed to initiate a renters' rights campaign.

The following semester, Urban Citizen and WOC students again canvassed door-to-door to inform residents of an upcoming renters' rights conference, during which renters could discuss their rights, testify as to their living conditions, and join a tenant's union dedicated to political mobilization on these issues. Students mobilized resident turnout, organized media attention, insured the attendance of public officials, and produced relevant action research reports on, for example, the state of renters rights, the 10 worst "Landlords from Hell," and strategies for change. About 50 renters attended, as did a number of state and local officials and media representatives. Many issues were discussed, but the fact that most renters in attendance were from HUDsubsidized Section 8 housing put that issue at the top of the agenda.

Created in the late 1970s to meet the needs of very low-income renters, the Section 8 program guaranteed subsidies to apartment owners who agreed to house low-income renters for 20 years. Section 8 quickly became the largest federal rental assistance program in U.S. history. At its high point, the program helped about three million families a year afford housing. Within the next few years, most Section 8 contracts will expire, giving owners a chance to "opt out" of providing low-income housing and to raise the rents on their properties to market levels. As open-market rents increase across America, many owners are doing this. In 1998, 17,000 Section 8 units disappeared across the nation, three times the total from the year before.

Currently, WOC students are playing a leading role in an increasingly successful SOS8 campaign in Denver. Students have organized tenants' associations in 15 buildings and have helped to bring over 500 residents into the SOS8 coalition. Students also accompany low-income residents to city council meetings on a weekly basis, where the residents testify as to the crisis and demand action. Students have produced action research reports documenting the crisis and possible solutions, and have delivered these reports to local officials. Students have brokered meetings with HUD staffers, state representatives, and local officials. Most militantly, in an attempt to catalyze action on the subject, students have organized street protests and demonstrations of 200-300 residents, who have disrupted city council hearings and task force meetings several times and have persuaded the mayor to meet with representatives of the SOS8 coalition.

Denver's governing officials are responding. As of this writing, the council has created an affordable housing task force staffed partly by SOS8 coalition members, has held official hearings on the issue, and has begun to craft local legislative responses. These responses include the creation of a multimillion dollar affordable housing trust fund, a proposed ordinance declaring lowincome housing a "public resource" and directing the city to buy certain private, low-income housing projects and convert them to nonprofit housing, a proposed ordinance requiring developers to include low-income housing in their new projects and to pay impact fees into the affordable housing trust fund, and official efforts to utilize condemnation and eminent domain powers to force one "opting out" Section 8 owner to sell his property to the city in order to maintain the low-income units permanently. These actions were forced to the front of the Denver government's agenda by the efforts of SOS8 organizers and researchers. Denver now sits at the cusp of transformation in its housing policies, 
and it has been led there by participants of a politicized service learning campaign.

\section{A Pedagogy of Liberation: Beyond Service into Transformation}

Service learning practitioners should quit apologizing for the fact that scholars and students can, in fact, speak truth to power; that our heritage as engaged scholars is not merely that of a healing nurse, but also reproachful Socratic gadfly. Service learning curricula should not consist only of Socratic challenges to power, but they should include such practices without embarrassment.

Including such kinds of service learning addresses community needs for transformation, addresses the desires of many professors to be more responsive to community needs, and addresses students' need for participating in a more holistic educational experience that unites knowledge with action. Giving one's course partly over to community collaborators and to the controlled chaos of social activism within a living and unpredictable community can yield serious pedagogical benefits. First of all, such a strategy recognizes that experiential learning helps many students improve their critical-thinking and problem-solving skills, and gain awareness of the political processes and the nature of citizenship (Beamer 1998; Brock and Cameron 1999; Dewey 1956, 1958; Fox and Ronkowski 1997; Friere 1970; Kolb 1984). Second, such a strategy makes political science programs more responsive to the many students who come to our discipline seeking what APSA's Task Force on Civic Education (1997) called meaningful "civic engagement" and "a personal sense of responsibility." Third, explicitly political models of service learning help students to interrogate more deeply the social role of the university and the responsibility of the educated to their community. Taking part in a politicized service learning program allows students and faculty to better understand the political implications of all we do and to better grapple with the political relationships among the knowledge, investigations, and teachings of a university and the established power structures of society.

I am well aware of the critique that such practices violate the norms of "academic neutrality" (Lisman 1998). The positivist, value-neutral bent of many in political science causes them to be suspicious of methods such as socially engaged participatory action research (Nyden et al. 1997, 17). In a recent $P S$ forum on advocacy in the classroom, Paul Gardner argued that "teachers should keep their personal opinions out of the classrooms" and should refuse to "advocate any one position." Students learn better from detached exposure to a variety of intellectual viewpoints, according to Gardner, and also when they "separate themselves from their own convictions" and "detach their thoughts from their emotions." Gardner concluded that "I do not believe students will consider ideas different from their own unless teachers work at keeping their own perspectives out of the classroom" $(1998,802$ -

03).

Any professor who embraces this philosophy is overly pessimistic concerning the ability of students, who are, after all, adults quite capable of honing their ideas and finding new perspectives through open and fairminded discussions of opinions-including the opinion of the instructor. Open and civil advocacy of a variety of viewpoints can be expected to nurture independent thought just as well as "passionate detachment" can (West 1998, 805). Alternative kinds of learning based on emotion and conviction should not be universally excluded from higher education. In fact, some edu- cation theorists hold that students learn better when they voice their own opinions and understandings than they do when they carefully detach from the learning process (see, e.g., Friere 1970; Myers and Tronto 1998).

Political engagement may be beneficial for instructors as well. Patricia Siplon recounted in a recent $P S$ article how she progressed from being only a scholar of the AIDS crisis to also being an AIDS activist. As she deepened her emotional engagement with the AIDS community and its political struggles, she found herself gaining "far greater access to information," a more true "understanding of the intensity of the experiences of ... subjects," and a deeper commitment to put her knowledge to practical use (1999, 577-81). Siplon's experience shows how political scientists who are too concerned with demarcating false and demoralizing lines between "scholar" and "activist" often fail to meet their professional and moral obligations. "To dispassionately describe and theorize about a tragedy like the AIDS epidemic in the name of 'good science' while doing nothing to stop it is the worst form of irresponsibility," she concluded (581).

Not all the resistance to justice advocacy service learning comes from faculty colleagues. Students may also disagree with the goal of becoming political activists. Occasionally, some of my students take exception to the left-leaning, transformational agenda of WOC and the Urban Citizen course. As a professor's obligation is to teach analytical and political skills to all students without requiring orthodoxy of either action or thought, I strive to productively integrate such student resistance into the course. Achieving such a result is not too difficult.

First, both WOC and the Urban Citizen are elective experiences that no student participates in without self-selecting. Students generally come to these projects knowing what to expect, and are excited by the projects. Still, Urban Citizen attracts students of all value orientations. To welcome all perspectives, it is made clear that, although certain 
action projects are laid out by the professors, any student or group of students can design a project of their choice, as long as it involves engagement with residents of a lowincome urban neighborhood. Alternative student projects have included marketing community arts and culture businesses, creating local business plans, working to bring more police attention to the community, and creating a hockey league for children from the area's public housing projects. Students sponsoring these projects were all more conservative than the average Urban Citizen student, and it was a great benefit to incorporate their broader perspectives into class discussions about urban poverty and the proper response to it. As professors, Jerry Jacks and 1 have discovered that opening the classroom to discussions of the underlying political assumptions of the action choices of students, and to the underlying values of the course, has led to broad satisfaction among a wide range of students.

Finally, I should note that a rare class offering avenues to advocacy and political engagement hardly constitutes a betrayal of the university's general commitment to academic neutrality. The university is constituted by a variety of classes, teachers, and teaching styles, and academic neutrality is maintained more by exposing students to all manner of perspectives and experiences during their entire college career than it is by carefully excising each and every instance of advocacy from all classes. Anyway, universities already house programs explicitly designed to teach students how to succeed within the mainstream political economy (e.g., business schools, economics departments, most engineering programs), and yet one rarely hears concerns for academic neutrality when such programs place interns with IBM, with corporate law firms, with downtown developers, or with international trade organizations. Left-leaning, justice advocacy service learning programs (generally rare and offered as electives) can not violate a principle of academic neutrality that does not, in fact, exist.

Refusing to admit this fact, instructors allow the potential of the service learning movement to be limited by governmental, corporate, and other institutional sponsors. Meek acceptance of guidelines to remain neutral and nonpolitical will shrink the parameters of the possible and will decrease the relevance of service learning programs to the needy communities they serve. Of course, there is no requirement that civically engaged service learning programs aimed at social transformation be left-leaning. Programs could as easily be affiliated with organizations like Focus on the Family and movements such as the property-rights rebellion, the anti-tax crusade, and the rightto-life movement. Clearly, some activist service learning programs can and should advance an agenda fundamentally different from that of Urban Citizen and WOC. Such programs will certainly be systemchallenging and transformative. Advancing the theory of the university as an agent of social transformation is less a call for one kind of ideological orthodoxy in political education, than it is a call for political relevance and transformational social engagement in political science programs across the ideological spectrum. My hope is to encourage educators to dedicate themselves to producing an engaged citizenry (right or left) by developing curricula that give students opportunities to directly engage social issues. Relevant political science instruction should inspire students to become active citizens, willing and able to pose meaningful challenges to standard operating procedures.

Throughout history, university engagement with the community has resulted in several thorough social shakings (e.g., the Settlement House movement, the Free Speech Movement, the civil rights and anti-Vietnam War campaigns, and the struggle against South African apartheid), but scientism and dedication to academic neutrality has substantially undermined the vision of the university as a source of independent social critique. Political scientists are now ordered to neutrality, which, in the realm of politics, means "irrelevancy." This "neutrality mandate" comes largely from institutional powers who wish to shape the moral and ideological direction of service learning in normalized and nonthreatening directions. Depoliticized, service learning is in danger of becoming mostly a downscaled, directservice welfare state operation: funded and directed in large part by the government itself through organizations like the Corporation for National Service and HUD.

We can, in fact, push back. For just as Piven and Cloward taught in their classic work, Poor People's Movements (1977), true transformation happens when people take risks and challenge the rulemakers, not when they seek accommodations within the structures others have built. Taking to the streets to find new and hidden truths will promote social transformation and also help students better discover the power of ideas and the responsibilities of citizenship. In the end, students may discover just what Socrates taught so long ago: The calling of a place of truth, of a place dedicated to universal human progress, is not to make accommodations to power so that it may survive, but to force power to make accommodations to it, so that we all may survive. 


\section{References}

APSA Task Force on Civic Education. 1997. "Statement of Purpose." PS: Political Science and Politics 30(December): 745.

—. 1998. "Expanded Articulation Statement: A Call for Reactions and Contributions." PS: Political Science and Politics 31(September): 636-67.

Barber, Benjamin. 1998. "A Mandate for Liberty: Requiring Education-Based Community Service." In The Essential Communitarian Reader, ed. Amitai Etzioni. New York: Rowman \& Littlefield.

- 1999. Address to the National Conference of the Campus Compact, Phoenix, AZ.

Beamer, Glenn. 1998. "Service Learning: What's a Political Scientist Doing in Yonkers?" PS: Political Science and Politics 31(September): 557-61.

Brock, Kathy L., and Beverly J. Cameron. 1999. "Enlivening Political Science Courses with Kolb's Learning Preference Model." PS: Political Science and Politics 32(June): 251-56.

Carr, James. 1999. "It's Not Just Academic: University-Community Partnerships Are Rebuilding Neighborhoods." Housing Facts and Findings 1:1-5.

Commager, Henry. 1960. "Foreword." In Twenty Years at Hull House, auth. Jane Addams. New York: Signet.

Dewey, John. 1956. The Child and the Curriculum; and The School and Society. Chicago: University of Chicago Press.

-. 1958. Experience and Nature. New York: Dover.

Ehrenhalt, Alan. 1988. Address to American Politics Seminar. University of California, Berkeley, April 10.

Ferman, Barbara, and Anne Shay. 1997. "The Academy Hits the Streets: Teaching Community-Based Research.” In Building
Community: Social Science in Action, ed. Philip Nyden et al. Thousand Oaks, CA: Pine Forge Press.

Fox, Richard L., and Shirley A. Ronkowski. 1997. "Learning Styles of Political Science Students." PS: Political Science and Politics 30(December): 732-37.

Friere, Paulo. 1970. Pedagogy of the Oppressed. New York: Continuum.

Gardner, Paul. 1998. "Teaching at its Best." PS: Political Science and Politics 31(December): 802-04.

Gorham, Eric. 1992. National Service, Citizenship, and Political Education. New York: State University of New York Press.

Kolb, D.A. 1984. Experiential Learning: Experience as the Source of Learning and Development. Englewood Cliffs, NJ: PrenticeHall.

Kraft, Richard. 1999. "Service Learning: An Introduction to Its Theory, Practice, and Effects." In Advances in Education Research, ed. Judy Craig. Washington, DC: National Library of Education.

Lisman, C. David. 1997. "The Tension of Theory and Practice in Service-Learning." In Tensions Inherent in Service-Leaming: Achieving Balance, ed. Terry Pickeral and Karen Peters. Mesa, AZ: Campus Compact National Center for Community Colleges.

—. 1998. Toward a Civil Society: Civic Literacy and Service Learning. Westport, CT: Bergin and Garvey.

Miller, James. 1987. Democracy Is in the Streets: From Port Huron to the Siege of Chicago. New York: Simon and Schuster. Myers, Joann, and Joan C. Tronto. 1998. "Truth' and Advocacy: A Feminist Perspective." PS: Political Science and Politics 31(December): 808-10.
Nader, Ralph. 1997. "How Political Scientists Can Change Politics." Presented at the Annual Meeting of the American Political Science Association, Washington, DC.

Nyden, Philip, et al., eds. 1997. Building Community: Social Science in Action. Thousand Oaks, CA: Pine Forge Press.

Palmer, P. 1996. Divided No More: A Movement Approach to Educational Reform. Dayton, OH: Higher Education Exchange, Kettering Foundation.

Piven, Frances Fox, and Richard Cloward. 1977. Poor People's Movements: Why They Succeed, How They Fail. New York: Pantheon.

Rhoades, Robert. 1998. "Critical Multiculturalism and Service Learning." New Directions for Teaching and Learning 73:39-46.

Rimmerman, Craig. 1997. The New Citizenship: Unconventional Politics, Activism, and Service. Boulder: Westview.

Siplon, Patricia. 1999. "Scholar, Witness, or Activist? The Lessons and Dilemmas of an AIDS Research Agenda." PS: Political Science and Politics 32(September): 577 81.

Stringer, Ernie, et al., eds. 1997. CommunityBased Ethnography: Breaking Traditional Boundaries of Research, Teaching and Learning. Mahwah, NJ: Lawrence Erlbaum Associates.

U.S. Department of Housing and Urban Development 1999. Building Higher Education-Community Development Corporation Partnerships. Washington, DC: U.S. Department of Housing and Urban Development.

West, Ellis M. 1998. "Some Proposed Guidelines for Advocacy in the Classroom." PS: Political Science and Politics 31(December): 805-07. 


\section{APSA Launches New Service Learning Web Site}

The development and adaptation of service learning programs is becoming more common in today's classroom. Political science departments across the country are following this trend. By actively encouraging participation in service experiences that are directly related to political science courses, political science departments are guiding students in applying political knowledge and skills they gain in the classroom and in learning first-hand the importance of civic engagement.

APSA has developed a new service learning web site to help political science faculty and departments better understand the role service learning can play in their classrooms. The site has been designed to

- Highlight the contribution of service learning to political science, especially in encouraging and engaging students in democratic practices

- $\quad$ Recognize the work of political scientists developing and assessing service learning

- Assist political science faculty and departments who want to learn how to integrate service learning into their courses and curricula

The site features "how-to" references (e.g., gaining institutional and administrative support for service learning), service learning program and course materials, information on professional opportunities and rewards, precollegiate resources, and information on receiving service learning news and joining an exchange on service learning.

APSA would like to include information about your service learning courses and programs on the website. Please contact us to servicelearning@apsanet.org to submit

- $\quad$ Service learning course syllabi

- Descriptions of service learning components in your department's curriculum

- $\quad$ References to published papers on service learning to be added to the web site

- $\quad$ Papers on service learning presented at the APSA Annual Meeting or at other professional meetings

The service learning site is linked to APSA's Teaching in Political Science and Civic Education sites and is located at www.apsanet.org/teach/service/

This service learning initiative is supported, in part, by a grant from Campus Compact with funding from The Pew Charitable Trusts. 


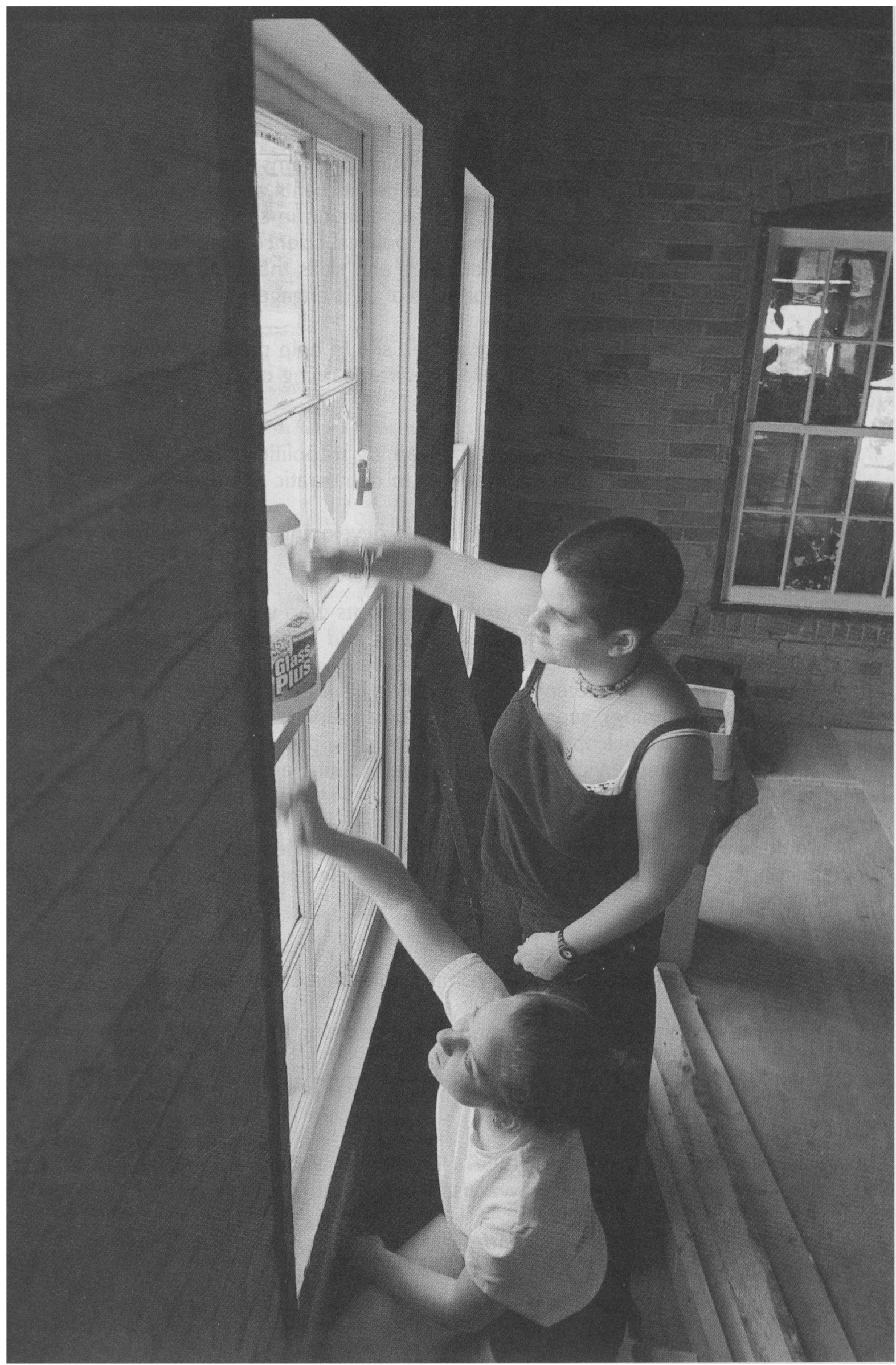

